\title{
"Researching the Research" in Prostate Cancer: A Comparative Bibliometric Analysis of the Top 100 Cited Articles in the Field of Prostate Cancer
}

\author{
Ahmed Adam ${ }^{a, b, c} \quad$ Reuben Ras $^{\mathrm{a}, \mathrm{b}, \mathrm{c}} \quad$ Amit S. Bhattu $^{\mathrm{d}} \quad$ Avi Raman $^{\mathrm{e}}$ Marlon Perera ${ }^{\mathrm{f}}$ \\ aDepartment of Urology, Helen Joseph Hospital; bepartment of Paediatric Urology, Rahima Moosa Mother \& Child (Coronation) \\ Hospital; 'The Division of Urology, Department of Surgery, Faculty of Health Sciences, University of the Witwatersrand, Johannesburg, \\ South Africa; 'dackson Memorial Hospital, University of Miami Health System, Miami, FL, USA; eRoyal Free Hospital, Pond Street, Hamp- \\ stead, London, UK; fDepartment of Surgery, Austin Health, University of Melbourne, Melbourne, Australia
}

\section{Key Words}

Prostate cancer $•$ Research $•$ Bibliometric analysis •

Top100 cited $\cdot$ Citation index $\cdot$ Institutions

\begin{abstract}
Background: To perform the first comparative bibliometric analysis of the "Top 100 (T100) cited articles in prostate cancer (PCa)". Materials and Methods: A comprehensive search using the Web of Science Database ( $v$ 5.21) covering the Web of Science ${ }^{\mathrm{TM}}$ Core Collection, BIOSIS Previews, Central Contents Connect, KCl-Korean Journal Database, MEDLINE, SciELO Index (February 2016) was performed, for all articles relevant to PCa. Results: The T100 were cited 582 to 3,387 times, and were published from 1966 to 2012 . The top 3 subcategories associated with PCa included: genetics/ biomarkers $(n=34)$, management $(n=25)$, and physiology $(n=11)$. T100 contributions from USA $(n=86)$, were most prominent. If the regional citation was corrected for percentage on research (citation record/percentage gross domestic product on research) a variation in the ranking was noted. Conclusion: The first bibliometric analysis in the field of PCa is presented. Regions that predominate the T100, include the United States and Europe. Articles published in higher
\end{abstract}

\section{KARGER}

(C) 2017 S. Karger AG, Basel

Fax +4161306 1234

E-Mail karger@karger.com

www.karger.com
Accessible online at: www.karger.com/cur impact factor journals, in English medium and content related to PCa research associated with genetics/bio-markers have the highest citation potential.

Copyright $\odot 2017$ S. Karger AG, Basel

\section{Introduction}

Prostate cancer $(\mathrm{PCa})$ is among the most prevalent cancers worldwide and is the third most common cause of cancer-associated mortality in men [1]. The recent worldwide PCa incidence of newly diagnosed cases has been estimated at $7.9 \%$ of all cancers [2]. Due to its' prevalence and the significant burden of diagnosis and treatment, research within PCa has always been a topical and high impact focus region within the contemporary medical literature.

Within medical literature, the number of citations that a published article achieves has been traditionally used to evaluate its intellectual impact it has on research within that topic or specific research focus. Despite the controversies associated with the Citation Index (CI) and the 
resulting Journal Impact Factor (IF), it is still a globally recognised parameter in the evaluation of academic research, or intellectual influence within any field [3].

To provide us with an understanding of "prostate cancer" research associated focus areas, the first ever bibliometric analysis in this research topic is performed. Information of the areas of greatest citation potential, regions performing high impact research, centers and authors responsible, journal platforms utilised were thus ascertained. Further, an independent rank of all relevant publications, including a comprehensive literature-wide CI-rating was to be performed within the field of PCa.

Therefore, we aimed to perform the first comprehensive, comparative bibliometric analysis of the "Top 100 most cited articles in the field of PCa" (T100).

\section{Materials and Methods}

\section{Search Strategy}

To identify the most cited articles in the field of "prostate cancer", a comprehensive search was performed using the Web of Science Database (v.5.21) (January 1, 1945 to February 2, 2016); covering the Web of Science ${ }^{\mathrm{TM}}$ Core Collection, BIOSIS Previews, Central Contents connect, KCI-Korean Journal Database, MEDLINE, SciELO Citation Index, Russian Science Citation and the Chinese Science Citation Database. Search keywords utilized included: prostate/prostatic cancer, prostate/prostatic carcinoma, prostate/prostatic neoplasm/s, and prostate/prostatic adenocarcinoma.

Restriction was not performed to "urology and nephrology" journals only, since other journals may have highly cited research that may fall outside this journal sub-category, but may still be related to $\mathrm{PCa}$ research. No language restrictions were applied.

\section{Citation and Publication Data}

Following the comprehensive search strategy performed on Web of Science Databases, the resulting outcome was sorted by "Times cited - highest to lowest". The highest 100 ranked articles were recorded. Data including publication year, journal of publication, authors, affiliated institutions, country of origin and citation data were extracted for analysis.

"Publication year" was determined as per indexing on the Web of Science Database. Journal IF data was obtained from the Journal of Citation Reports [4]. The "primary author" was determined as the first author on the respective publication. In the case of coauthorship, the first listed author was determined as the primary author. "Country of origin" was based on the territory or country of the author affiliation as listed within the publication. "Affiliated institutions" were based on the institutions listed within the publication. In the setting of multi-institutional studies, each institution was counted individually. Ranking of respective institutions were based on the Shanghai Academic Ranking of World Universities (ARWU), Leiden and Quacquarelli Symonds (QS) World Ranking, as ranked on July 25, 2016 [5-7].

Citation data was obtained as calculated by Web of Science Databases. To adjust for the "exposure time" of articles published

Top 100 Cited Articles in Prostate Cancer prior to 2016, an Adjusted Citation Index (ACI), used in prior bibliometric analysis [8], was also calculated, using the equation: ACI $=$ Number of citations/(2016 Year of publication).

To adjust for the "expenditure" on research, the ranking was adjusted by percentage of gross domestic product (GDP) on research per country. GDP data was obtained from the World Bank data [9]. To perform this adjustment, the following equation from a previous publication [10], was utilized: Corrected score for percentage GDP on research $=$ Citation record/percentage GDP on research.

\section{Results}

$A C I$

The T100 are listed in table 1 . These articles were cited 582 to 3,387 times, with a median citation rate of 853. Articles featuring in the T100 were all published from 1966 to 2012.

Recalculation using the ACI resulted in a drastic change of the overall ranking, with the previously seventh ranked most cited paper [11], ranking highest (table 1). Further, the initially ranked sixty-ninth paper [12], after applying the ACI, was ranked last of the T100 at 100.

\section{Journals}

General medical or oncology journals dominated the top positions within this category (table 2). The New England Journal of Medicine had published most of the T100 publications $(n=21)$. It also had the highest IF from the list of Journals assessed. Among the "nephrology and urology" journal category, The Journal of Urology had the most publications $(\mathrm{n}=5)$, followed by European Urology $(\mathrm{n}=2)$.

\section{Country of Origin versus GDP\% on Research,}

Adjusted Score, and Adjusted Rank

When reviewing the geographic origin of the T100, contributions from USA $(n=86)$, Canada $(n=16)$ and United Kingdom $(n=15)$ were most prominent. The corresponding record count is tabulated in table 3 (countries where 2 or more papers of the T100 originated), and the corresponding figure 1.

In ranking various countries research output, the correcting formula for percentage spent on GDP was utilised [10]. Despite this adjustment, USA still featured most prominently in the T100.

\section{Article Category and Type}

A further breakdown of the T100, into the research associated categories based on the "Main content" category and the listed "Web of Science category" was as- 
Table 1. The T100 cited articles in PCa

\begin{tabular}{|c|c|c|c|c|}
\hline Rank & Cites & Journal article title & Adjusted CI & Adjusted rank \\
\hline 1 & 3,387 & $\begin{array}{l}\text { Li J, et al: PTEN, a putative protein tyrosine phosphatase gene mutated in human brain, breast, and prostate cancer. Science } \\
\text { 1997;275:1943-1947. }\end{array}$ & 178.26 & 7 \\
\hline 2 & 2,638 & $\begin{array}{l}\text { Tannock IF, et al: Docetaxel plus prednisone or mitoxantrone plus prednisone for advanced prostate cancer. N Engl J Med } \\
\text { 2004;351:1502-1512. }\end{array}$ & 219.83 & 5 \\
\hline 3 & 1,967 & $\begin{array}{l}\text { Petrylak DP, et al: Docetaxel and estramustine compared with mitoxantrone and prednisone for advanced refractory prostate cancer. } \\
\text { N Engl J Med 2004;351:1513-1520. }\end{array}$ & 163.92 & 8 \\
\hline 4 & 1,910 & Schroeder FH, et al: Screening and prostate cancer mortality in a randomized European study. N Engl J Med 2009;360:1320-1328. & 272.86 & 2 \\
\hline 5 & 1,828 & $\begin{array}{l}\text { D'Amico AV, et al: Biochemical outcome after radical prostatectomy, external beam radiation therapy, or interstitial radiation therapy } \\
\text { for clinically localized prostate cancer. JAMA 1998;280:969-974. }\end{array}$ & 101.56 & 19 \\
\hline 6 & 1,801 & Tomlins SA, et al: Recurrent fusion of TMPRSS2 and ETS transcription factor genes in prostate cancer. Science 2005;310:644-648. & 163.73 & 9 \\
\hline 7 & 1,726 & Kantoff PW, et al: Sipuleucel-T immunotherapy for castration-resistant prostate cancer. N Engl J Med 2010;363:411-422. & 287.67 & 1 \\
\hline 8 & 1,697 & Stamey TA, et al: Prostate-specific antigen as a serum marker for adenocarcinomar of the prostate. N Engl J Med 1987;317:909-916. & 58.52 & 48 \\
\hline 9 & 1,585 & Collins AT, et al: Prospective identification of tumorigenic prostate cancer stem cells. Cancer Res 2005;65:10946-10951. & 144.09 & 13 \\
\hline 10 & 1,492 & $\begin{array}{l}\text { Catalona WJ, et al: Measurement of prostatic-specific antigen in serum as a screening test for prostate cancer. N Engl J Med } \\
\text { 1991;324:1156-1161. }\end{array}$ & 59.68 & 45 \\
\hline 11 & 1,480 & Chan JM, et al: Plasma insulin-like growth factor I and prostate cancer risk: a prospective study. Science 1998;279:563-566. & 82.22 & 30 \\
\hline 12 & 1,450 & Thompson IM, et al: The influence of finasteride on the development of prostate cancer. N Engl J Med 2003;349:215-224. & 111.54 & 18 \\
\hline 13 & 1,407 & Andriole GL, et al: Mortality results from a randomized prostate cancer screening trial. N Engl J Med 2009;360:1310-1319. & 201 & 6 \\
\hline 14 & 1,405 & $\begin{array}{l}\text { Gleason DF, et al: Prediction of prognosis for prostatic adenocarcinoma by combined histological grading and clinical staging. J Urol } \\
\text { 1974;111:58-64. }\end{array}$ & 33.45 & 86 \\
\hline 15 & 1,361 & Horoszewicz JS, et al: LNCaP model of human prostatic carcinoma. Cancer Res 1983;43:1809-1818. & 41.24 & 73 \\
\hline 16 & 1,352 & Kaighn ME, et al: Establishment and characterization of a human prostatic carcinoma cell line (PC-3). Invest Urol 1979;17:16-23. & 36.54 & 80 \\
\hline 17 & 1,327 & Feldman BJ, et al: The development of androgen-independent prostate cancer. Nat Rev Cancer 2001;1:34-45. & 88.47 & 27 \\
\hline 18 & 1,310 & Varambally S, et al: The polycomb group protein EZH2 is involved in progression of prostate cancer. Nature 2002;419:624-629. & 93.57 & 22 \\
\hline 19 & 1,300 & Weidner N, et al: Tumor angiogenesis correlates with metastasis in invasive prostate carcinoma. Am J Pathol 1993;143:401-409. & 56.52 & 52 \\
\hline 20 & 1,282 & $\begin{array}{l}\text { Partin AW, et al: Combination of prostate-specific antigen, clinical stage, and gleason score to predict pathological stage of localized } \\
\text { prostate cancer - A multi-institutional update. JAMA 1997;277:1445-1451. }\end{array}$ & 67.47 & 37 \\
\hline 21 & 1,240 & Singh D, et al: Gene expression correlates of clinical prostate cancer behaviour. Cancer Cell 2002;1:203-209. & 88.57 & 26 \\
\hline 22 & 1,183 & $\begin{array}{l}\text { Thompson IM, et al: Prevalence of prostate cancer among men with a prostate-specific antigen level }<=4.0 \mathrm{ng} \text { per milliliter. N Engl } \\
\text { J Med 2004;350:2239-2246. }\end{array}$ & 98.58 & 21 \\
\hline 23 & 1,178 & De Bono JS, et al: Abiraterone and increased survival in metastatic prostate cancer. N Engl J Med 2011;364:1995-2005. & 235.6 & 3 \\
\hline 24 & 1,169 & Dhanasekaran SM, et al: Delineation of prognostic biomarkers in prostate cancer. Nature 2001;412:822-826. & 77.93 & 32 \\
\hline 25 & 1,162 & $\begin{array}{l}\text { Crawford ED, et al: A controlled trial of leuprolide with and without flutamide in prostatic carcinoma. N Engl J Med 1989;321:419- } \\
424 \text {. }\end{array}$ & 43.04 & 66 \\
\hline 26 & 1,097 & $\begin{array}{l}\text { Harisinghani MG, et al: Noninvasive detection of clinically occult lymph-node metastases in prostate cancer. N Engl J Med } \\
\text { 2003;348:2491-2495. }\end{array}$ & 84.38 & 29 \\
\hline 27 & 1,093 & $\begin{array}{l}\text { Epstein JI, et al: Pathological and clinical findings to predict tumor extent of nonpalpable (stage T1c) prostate cancer. JAMA } \\
\text { 1994;271:368-374. }\end{array}$ & 49.68 & 58 \\
\hline 28 & 1,083 & $\begin{array}{l}\text { Bolla M, et al: Long-term results with immediate androgen suppression and external irradiation in patients with locally advanced } \\
\text { prostate cancer (an EORTC study): a phase III randomised trial. Lancet 2002;360:103-108. }\end{array}$ & 77.36 & 34 \\
\hline 29 & 1,082 & $\begin{array}{l}\text { Tannock IF, et al: Chemotherapy with mitoxantrone plus prednisone or prednisone alone for symptomatic hormone-resistant prostate } \\
\text { cancer: a Canadian randomized trial with palliative end points. J Clin Oncol 1996;14:1756-1764. }\end{array}$ & 54.1 & 55 \\
\hline 30 & 1,068 & $\begin{array}{l}\text { Bolla M, et al: Improved survival in patients with locally advanced prostate cancer treated with radiotherapy and goserelin. N Engl J } \\
\text { Med 1997;337:295-300. }\end{array}$ & 56.21 & 53 \\
\hline 31 & 1,045 & $\begin{array}{l}\text { Zhong H, et al: Modulation of hypoxia-inducible factor } 1 \text { alpha expression by the epidermal growth factor/phosphatidylinositol } \\
\text { 3-kinase/PTEN/AKT/FRAP pathway in human prostate cancer cells: Implications for tumor angiogenesis and therapeutics. Cancer } \\
\text { Res 2000;60:1541-1545. }\end{array}$ & 65.31 & 38 \\
\hline 32 & 1,030 & $\begin{array}{l}\text { Oesterling JE: Prostate specific antigen: a critical assessment of the most useful tumor markers for adenocarcinoma of the prostate. } \\
\text { J Urol 1991;145:907-923. }\end{array}$ & 41.2 & 74 \\
\hline 33 & 978 & $\begin{array}{l}\text { McDonnell TJ, et al: Expression of the protooncogene bcl-2 in the prostate and its association with emergence of androgen-indepen- } \\
\text { dent prostate cancer. Cancer Res 1992;52:6940-6944. }\end{array}$ & 40.75 & 75 \\
\hline 34 & 960 & Taylor BS, et al: Integrative genomic profiling of human prostate cancer. Cancer Cell 2010;18:11-22. & 160 & 10 \\
\hline 35 & 959 & $\begin{array}{l}\text { Epstein JI, et al: The } 2005 \text { International Society of Urological Pathology (ISUP) consensus conference on Gleason grading of prostatic } \\
\text { carcinoma. Am J Surg Pathol 2005;29:1228-1242. }\end{array}$ & 87.18 & 28 \\
\hline 36 & 954 & $\begin{array}{l}\text { Catalona WJ, et al: Comparison of digital rectal examination and serum prostate specific antigen in the early detection of prostate } \\
\text { cancer: results of a multicenter clinical trial of } 6,630 \text { men. J Urol 1994;151:1283-1290. }\end{array}$ & 43.36 & 64 \\
\hline 37 & 925 & Sanda MG, et al: Quality of life and satisfaction with outcome among prostate-cancer survivors. N Engl J Med 2008;358:1250-1261. & 115.63 & 17 \\
\hline 38 & 921 & $\begin{array}{l}\text { de Bono JS, et al: Prednisone plus cabazitaxel or mitoxantrone for metastatic castration-resistant prostate cancer progressing after } \\
\text { docetaxel treatment: a randomised open-label trial. Lancet 2010;376:1147-1154. }\end{array}$ & 153.5 & 11 \\
\hline 39 & 918 & $\begin{array}{l}\text { Roach M, et al: Defining biochemical failure following radiotherapy with or without hormonal therapy in men with clinically lo- } \\
\text { calized prostate cancer: Recommendations of the RTOG-ASTRO Phoenix Consensus Conference. Int J Radiat Oncol Biol Phys } \\
\text { 2006;65:965-974. }\end{array}$ & 91.8 & 25 \\
\hline 40 & 903 & $\begin{array}{l}\text { Sreekumar A, et al: Metabolomic profiles delineate potential role for sarcosine in prostate cancer progression. Nature 2009;457:910 } \\
-914 \text {. }\end{array}$ & 129 & 14 \\
\hline 41 & 901 & Giovannucci E, et al: Intake of carotenoids and retinol in relation to risk of prostate cancer. J Natl Cancer Inst 1995;87:1767-1776. & 42.9 & 69 \\
\hline 42 & 899 & $\begin{array}{l}\text { Saad F, et al: A randomized, placebo-controlled trial of zoledronic acid in patients with hormone-refractory metastatic prostate carci- } \\
\text { noma. J Natl Cancer Inst 2002;94:1458-1468. }\end{array}$ & 64.21 & 40 \\
\hline 43 & 891 & $\begin{array}{l}\text { Lippman SM, et al: Effect of selenium and vitamin E on risk of prostate cancer and other cancers: the Selenium and Vitamin E Cancer } \\
\text { Prevention Trial ( SELECT). JAMA 2009;301:39-51. }\end{array}$ & 127.29 & 15 \\
\hline 44 & 880 & Scher HI, et al: Increased survival with enzalutamide in prostate cancer after chemotherapy. N Engl J Med 2012;367:1187-1197. & 220 & 4 \\
\hline 45 & 877 & $\begin{array}{l}\text { Olumi AF, et al: Carcinoma-associated fibroblasts direct tumor progression of initiated human prostatic epithelium. Cancer Res } \\
\text { 1999;59:5002-5011. }\end{array}$ & 51.59 & 56 \\
\hline 46 & 868 & $\begin{array}{l}\text { Visakorpi T, et al: In vivo amplification of the androgen receptor gene and progression of human prostate cancer. Nat Genet } \\
\text { 1995;9:401-406. }\end{array}$ & 41.33 & 72 \\
\hline
\end{tabular}




\begin{tabular}{|c|c|c|c|c|}
\hline Rank & Cites & Journal article title & Adjusted CI & Adjusted rank \\
\hline 47 & 862 & Stone KR, et al: Isolation of a human prostate carcinoma cell line (DU 145). Int J Cancer 1978;21:274-281. & 22.68 & 98 \\
\hline 48 & 861 & $\begin{array}{l}\text { Pollack A, et al: Prostate cancer radiation dose response: results of the M.D. Anderson phase III randomized trial. Int J Radiat Oncol } \\
\text { Biol Phys 2002;53:1097-1105. }\end{array}$ & 61.5 & 43 \\
\hline 49 & 855 & $\begin{array}{l}\text { Stenman UH, et al: A complex between prostate-specific antigen and alpha 1-antichymotrypsin is the major form of prostate-spe- } \\
\text { cific antigen in serum of patients with prostatic cancer: assay of the complex improves clinical sensitivity for cancer. Cancer Res } \\
\text { 1991;51:222-226. }\end{array}$ & 34.2 & 85 \\
\hline 50 & 853 & Greenberg NM, et al: Prostate cancer in a transgenic mouse. Proc Natl Acad Sci USA 1995;92:3439-3443. & 40.62 & 76 \\
\hline 51 & 853 & $\begin{array}{l}\text { Partin AW, et al: The use of prostate specific antigen, clinical stage and Gleason score to predict pathological stage in men with local- } \\
\text { ized prostate cancer. J Urol 1993;150:110-114. }\end{array}$ & 37.09 & 78 \\
\hline 52 & 822 & Bill-Axelson A, et al: Radical prostatectomy versus watchful waiting in early prostate cancer. N Engl J Med 2005;352:1977-1984. & 74.73 & 36 \\
\hline 53 & 793 & $\begin{array}{l}\text { Messing EM, et al: Immediate hormonal therapy compared with observation after radical prostatectomy and pelvic lymphadenectomy } \\
\text { in men with node-positive prostate cancer. N Engl J Med 1999;341:1781-1788. }\end{array}$ & 46.65 & 63 \\
\hline 54 & 791 & $\begin{array}{l}\text { Taplin ME, et al: Mutation of the androgen-receptor gene in metastatic androgen-independent prostate cancer. N Engl J Med } \\
\text { 1995;332:1393-1398. }\end{array}$ & 37.67 & 77 \\
\hline 55 & 774 & $\begin{array}{l}\text { Kattan MW, et al: A preoperative nomogram for disease recurrence following radical prostatectomy for prostate cancer. J Natl Cancer } \\
\text { Inst 1998;90:766-771. }\end{array}$ & 43 & 67 \\
\hline 56 & 759 & $\begin{array}{l}\text { Adam BL, et al: Serum protein fingerprinting coupled with a pattern-matching algorithm distinguishes prostate cancer from benign } \\
\text { prostate hyperplasia and healthy men. Cancer Res } 2002 ; 62: 3609-3614 \text {. }\end{array}$ & 54.21 & 54 \\
\hline 57 & 746 & $\begin{array}{l}\text { Catalona WJ, et al: Detection of organ-confined prostate cancer is increased through prostate-specific antigen-based screening. JAMA } \\
\text { 1993;270:948-954. }\end{array}$ & 32.43 & 88 \\
\hline 58 & 745 & $\begin{array}{l}\text { Scher HI, et al: Design and end points of clinical trials for patients with progressive prostate cancer and castrate levels of testosterone: } \\
\text { Recommendations of the prostate cancer clinical trials working group. J Clin Oncol 2008;26:1148-1159. }\end{array}$ & 93.13 & 23 \\
\hline 59 & 740 & Yeager M, et al: Genome-wide association study of prostate cancer identifies a second risk locus at 8q24. Nat Genet 2007;39:645-649. & 82.22 & 31 \\
\hline 60 & 738 & Litwin MS, et al: Quality-of-life outcomes in men treated for localized prostate cancer. JAMA 1995;273:129-135. & 35.14 & 83 \\
\hline 61 & 736 & $\begin{array}{l}\text { Bubley GJ, et al: Eligibility and response guidelines for phase II clinical trials in androgen-independent prostate cancer: Recommen- } \\
\text { dations from the prostate-specific antigen working group. J Clin Oncol 1999;17:3461-3467. }\end{array}$ & 43.29 & 65 \\
\hline 62 & 735 & Heidenreich A, et al: EAU guidelines on prostate cancer. Eur Urol 2008;53:68-80. & 91.88 & 24 \\
\hline 63 & 734 & Dong JT, et al: KAI1, a metastasis suppressor gene for prostate cancer on human chromosome 11p11.2. Science 1995;268:884-886. & 34.95 & 84 \\
\hline 64 & 726 & Heinlein CA, et al: Androgen receptor in prostate cancer. Endocr Rev 2004;25:276-308. & 60.5 & 44 \\
\hline 65 & 725 & $\begin{array}{l}\text { Heidenreich A, et al: EAU guidelines on prostate cancer. Part 1: screening, diagnosis, and treatment of clinically localised disease. } \\
\text { Eur Urol 2011;59:61-71. }\end{array}$ & 145 & 12 \\
\hline 66 & 710 & $\begin{array}{l}\text { Craft N, et al: A mechanism for hormone-independent prostate cancer through modulation of androgen receptor signaling by the HER- } \\
\text { 2/neu tyrosine kinase. Nat Med 1999;5:280-285. }\end{array}$ & 41.76 & 70 \\
\hline 67 & 707 & $\begin{array}{l}\text { Lapointe J, et al: Gene expression profiling identifies clinically relevant subtypes of prostate cancer. Proc Natl Acad Sci USA } \\
\text { 2004;101:811-816. }\end{array}$ & 58.92 & 47 \\
\hline 68 & 699 & Tran C, et al: Development of a second generation antiandrogen for treatment of advanced prostate cancer. Science 2009;324:787-790. & 99.86 & 20 \\
\hline 69 & 698 & Gleason DF: Classification of prostatic carcinomas. Cancer Chemother Rep 1966;50:125-128. & 13.96 & 100 \\
\hline 70 & 692 & $\begin{array}{l}\text { McNeal JE, et al: Zonal distribution of prostatic adenocarcinoma. Correlation with histologic pattern and direction of spread. Am J } \\
\text { Surg Pathol 1988;12:897-906. }\end{array}$ & 24.71 & 96 \\
\hline 71 & 691 & Chodak GW, et al: Results of conservative management of clinically localized prostate cancer. N Engl J Med 1994;330:242-248. & 31.41 & 91 \\
\hline 72 & 678 & $\begin{array}{l}\text { Zietman AL, et al: Comparison of conventional-dose vs high-dose conformal radiation therapy in clinically localized adenocarcinoma } \\
\text { of the prostate: a randomized controlled trial. JAMA 2005;294:1233-1239. }\end{array}$ & 61.64 & 42 \\
\hline 73 & 667 & $\begin{array}{l}\text { Zelefsky MJ, et al: Dose escalation with three-dimensional conformal radiation therapy affects the outcome in prostate cancer. Int J } \\
\text { Radiat Oncol Biol Phys 1998;41:491-500. }\end{array}$ & 37.06 & 79 \\
\hline 74 & 663 & $\begin{array}{l}\text { Stanford JL, et al: Urinary and sexual function after radical prostatectomy for clinically localized prostate cancer: the prostate cancer } \\
\text { outcomes study. JAMA 2000;283:354-360. }\end{array}$ & 41.44 & 71 \\
\hline 75 & 657 & $\begin{array}{l}\text { Catalona WJ, et al: Use of the percentage of free prostate-specific antigen to enhance differentiation of prostate cancer from benign } \\
\text { prostatic disease: a prospective multicenter clinical trial. JAMA } 1998 ; 279: 1542-1547 \text {. }\end{array}$ & 36.5 & 81 \\
\hline 76 & 656 & Nelson WG, et al: Mechanisms of disease: prostate cancer. N Engl J Med 2003;349:366-381. & 50.46 & 57 \\
\hline 77 & 656 & $\begin{array}{l}\text { Taichman RS, et al: Use of the stromal cell-derived factor-1/CXCR4 pathway in prostate cancer metastasis to bone. Cancer Res } \\
2002 ; 62: 1832-1837 \text {. }\end{array}$ & 46.86 & 62 \\
\hline 78 & 655 & $\begin{array}{l}\text { Albertsen PC, et al: 20-year outcomes following conservative management of clinically localized prostate cancer. JAMA } \\
\text { 2005;293:2095-2101. }\end{array}$ & 59.55 & 46 \\
\hline 79 & 651 & $\begin{array}{l}\text { Graff JR, et al: E-cadherin expression is silenced by DNA hypermethylation in human breast and prostate carcinomas. Cancer } \\
\text { Res1995;55:5195-5199. }\end{array}$ & 31 & 92 \\
\hline 80 & 644 & $\begin{array}{l}\text { Partin AW, et al: Contemporary update of prostate cancer staging nomograms (Partin Tables) for the new millennium. Urology } \\
\text { 2001;58:843-848. }\end{array}$ & 42.93 & 68 \\
\hline 81 & 642 & $\begin{array}{l}\text { Keating NL, et al: Diabetes and cardiovascular disease during androgen deprivation therapy for prostate cancer. J Clin Oncol } \\
2006 ; 24: 4448-4456 \text {. }\end{array}$ & 64.2 & 41 \\
\hline 82 & 639 & Shahinian VB, et al: Risk of fracture after androgen deprivation for prostate cancer. N Engl J Med 2005;352:154-164. & 58.09 & 50 \\
\hline 83 & 634 & $\begin{array}{l}\text { Freedland SJ, et al: Risk of prostate cancer-specific mortality following biochemical recurrence after radical prostatectomy. JAMA } \\
2005 ; 294: 433-439 \text {. }\end{array}$ & 57.64 & 51 \\
\hline 84 & 633 & $\begin{array}{l}\text { Bookstein R, et al: Suppression of tumorigenicity of human prostate carcinoma cells by replacing a mutated RB gene. Science } \\
\text { 1990;247:712-715. }\end{array}$ & 24.35 & 97 \\
\hline 85 & 625 & Gleason DF: Histologic grading of prostate cancer: a perspective. Hum Pathol 1992;23:273-279. & 26.04 & 94 \\
\hline 86 & 623 & $\begin{array}{l}\text { de Bono JS, et al: Circulating tumor cells predict survival benefit from treatment in metastatic castration-resistant prostate cancer. Clin } \\
\text { Cancer Res 2008;14:6302-6309. }\end{array}$ & 77.88 & 33 \\
\hline 87 & 623 & $\begin{array}{l}\text { Draisma G, et al: Lead times and overdetection due to prostate-specific antigen screening: estimates from the European randomized } \\
\text { study of screening for prostate cancer. J Natl Cancer Inst 2003;95:868-878. }\end{array}$ & 47.92 & 60 \\
\hline 88 & 615 & Gronberg H: Prostate cancer epidemiology. Lancet 2003;361:859-864. & 47.31 & 61 \\
\hline 89 & 611 & $\begin{array}{l}\text { Fizazi K, et al: Denosumab versus zoledronic acid for treatment of bone metastases in men with castration-resistant prostate cancer: } \\
\text { a randomised, double-blind study. Lancet } 2011 ; 377: 813-822 \text {. }\end{array}$ & 122.2 & 16 \\
\hline 90 & 611 & $\begin{array}{l}\text { Kantoff PW, et al: Hydrocortisone with or without mitoxantrone in men with hormone-refractory prostate cancer: results of the cancer } \\
\text { and leukemia group B } 9182 \text { study. J Clin Oncol 1999;17:2506-2513. }\end{array}$ & 35.94 & 82 \\
\hline 91 & 609 & $\begin{array}{l}\text { Giovannucci E, et al: The CAG repeat within the androgen receptor gene and its relationship to prostate cancer. Proc Natl Acad Sci } \\
\text { USA 1997;94:3320-3323. }\end{array}$ & 32.05 & 89 \\
\hline
\end{tabular}




\begin{tabular}{|c|c|c|c|c|}
\hline Rank & Cites & Journal article title & Adjusted CI & Adjusted rank \\
\hline 92 & 603 & Thomas G, et al: Multiple loci identified in a genome-wide association study of prostate cancer. Nat Genet 2008;40:310-315. & 75.38 & 35 \\
\hline 93 & 601 & Haldar S, et al: Taxol induces bcl-2 phosphorylation and death of prostate cancer cells. Cancer Res 1996;56:1253-1255. & 30.05 & 93 \\
\hline 94 & 598 & $\begin{array}{l}\text { Harries LW, et al: Identification of genetic polymorphisms at the glutathione S-transferase Pi locus and association with susceptibility } \\
\text { to bladder, testicular and prostate cancer. Carcinogenesis } 1997 ; 18: 641-644 \text {. }\end{array}$ & 31.47 & 90 \\
\hline 95 & 596 & $\begin{array}{l}\text { Colombel M, et al: Detection of the apoptosis-suppressing oncoprotein bc1-2 in hormone-refractory human prostate cancers. Am J } \\
\text { Pathol 1993;143:390-400. }\end{array}$ & 25.91 & 95 \\
\hline 96 & 589 & $\begin{array}{l}\text { Heinonen OP, et al: Prostate cancer and supplementation with alpha-tocopherol and beta-carotene: incidence and mortality in a con- } \\
\text { trolled trial. J Natl Cancer Inst 1998;90:440-446. }\end{array}$ & 32.72 & 87 \\
\hline 97 & 588 & $\begin{array}{l}\text { Saad F, et al: Long-term efficacy of zoledronic acid for the prevention of skeletal complications in patients with metastatic hor- } \\
\text { mone-refractory prostate cancer. J Natl Cancer Inst 2004;96:879-882. }\end{array}$ & 49 & 59 \\
\hline 98 & 585 & $\begin{array}{l}\text { Small EJ, et al: Placebo-controlled phase III trial of immunologic therapy with sipuleucel-T (APC8015) in patients with metastatic, } \\
\text { asymptomatic hormone refractory prostate cancer. J Clin Oncol 2006;24:3089-3094. }\end{array}$ & 58.5 & 49 \\
\hline 99 & 585 & $\begin{array}{l}\text { Cooner WH, et al: Prostate cancer detection in a clinical urological practice by ultrasonography, digital rectal examination and prostate } \\
\text { specific antigen. J Urol 1990;143:1146-1154. }\end{array}$ & 22.5 & 99 \\
\hline 100 & 582 & $\begin{array}{l}\text { Gudmundsson J, et al: Genome-wide association study identifies a second prostate cancer susceptibility variant at } 8 \mathrm{q} 24 \text {. Nat Genet } \\
\text { 2007;39:631-637. }\end{array}$ & 64.67 & 39 \\
\hline
\end{tabular}

Table 2. The most frequently cited journals featured in the T100

\begin{tabular}{llcc}
\hline Journal & $\begin{array}{l}\text { Papers } \\
\text { within T100 }\end{array}$ & $\begin{array}{l}\text { Latest journal } \\
\text { IF 2014 }\end{array}$ & $\begin{array}{l}\text { Cumulative num- } \\
\text { ber of citations }\end{array}$ \\
\hline N Engl J Med & 21 & 55.873 & 26,172 \\
JAMA & 11 & 35.289 & 9,865 \\
Cancer Res & 10 & 9.329 & 9,368 \\
J Clin Oncol & 6 & 18.443 & 4,401 \\
J Natl Cancer Inst & 6 & 12.583 & 4,374 \\
Science & 6 & 33.611 & 8,734 \\
J Urol & 5 & 4.36 & 4,827 \\
Lancet & 4 & 45.217 & 3,230 \\
Nat Genet & 4 & 29.352 & 2,793 \\
Int J Radiat Oncol Biol & 3 & 4.258 & 2,446 \\
Phys & & & \\
Nature & 3 & 41.456 & 3,382 \\
Proc Natl Acad Sci USA & 3 & 9.674 & 2,169 \\
Am J Pathol & 2 & 5.145 & 1,896 \\
Am J Surg Pathol & 2 & 5.145 & 1,651 \\
Cancer Cell & 2 & 23.3 & 2,200 \\
Eur Urol & 2 & 13.938 & 1,460 \\
\hline
\end{tabular}

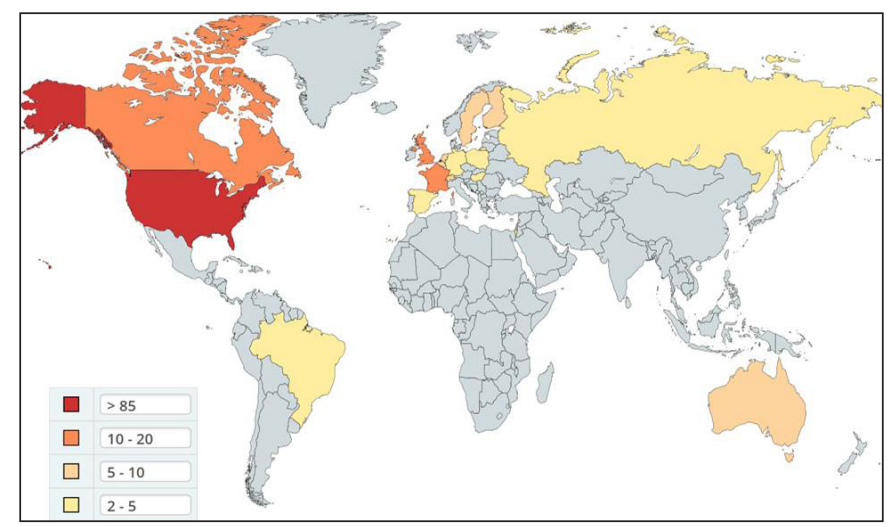

Fig. 1. World map of the centers of origin of the T100 (Due to international collaboration during certain publications, more than 100 centres were represented in total). sessed. Of these categories; genetics and biomarkers $(\mathrm{n}=$ $34)$, management of PCa $(n=25)$, physiology/biology/ pathophysiology $(\mathrm{n}=11)$ and content related to classification/grading/staging/nomograms $(n=11)$ were most prominent (fig. 2). If the prepopulated "Web of Science" category within the T100 is further analysed, then $\mathrm{PCa}$ research ranked under medicine general internal $(n=36)$, oncology $(n=31)$, multidisciplinary sciences $(n=12)$, urology nephrology $(n=9)$ is most featured (fig. 3$)$. Of the T100 articles, article types included original articles $(n=93)$, reviews $(n=4)$, notes $(n=2)$ and proceedings paper $(\mathrm{n}=1)$.

Performance within T100 over Time-Frames [5 Year Intervals]

Allocating number of articles within 5 year intervals from 1990, revealed the most "intellectually productive" time frame being from 1995 to 1999 . With the most prolific year being the year 2005, when 8 papers within the T100 were published within that year (fig. 4).

\section{Center of Origin (University or Center) versus Inter-} national Rank (ARWU, QS, Leidin Ranking System)

Research centers or universities with at least 5 papers within the T100 were tabulated (table 4). Harvard University was the institution that had the most T100 contributions $(n=20)$ within this review. The center responsible for the most T100, was observed to be within the top 2 of all the University rankings assessed.

Centers or universities with at least 5 citations within the T100 have been listed. Three research centers (non -university centers) were also observed within this list; National Cancer Institute, Memorial Sloan Kettering Cancer Center and the Brigham and Women's Hospital. 
Table 3. Individual countries record of articles within the T100 cited articles versus their percentage expenditure of research (Due to collaboration within many publications, the cumulative total exceeds 100).

\begin{tabular}{|c|c|c|c|c|c|}
\hline Country & $\begin{array}{l}\text { Record number of arti- } \\
\text { cles within the T100 }\end{array}$ & $\begin{array}{l}\text { Percentage GDP spent on } \\
\text { research and development }\end{array}$ & $\begin{array}{l}\text { Most recent } \\
\text { year listed }\end{array}$ & $\begin{array}{l}\text { Corrected for percentage on research } \\
\text { (Citation record/\%GDP on research) }\end{array}$ & Adjusted rank \\
\hline USA & 86 & 2.81 & 2012 & 40.60 & 1 \\
\hline Canada & 16 & 1.62 & 2013 & 9.87 & 2 \\
\hline France & 13 & 2.23 & 2013 & 5.82 & 5 \\
\hline $\begin{array}{l}\text { United Kingdom } \\
\text { (England + Scotland + Wales })\end{array}$ & $\begin{array}{l}15 \\
(10+3+2)\end{array}$ & 1.63 & 2013 & 9.20 & 3 \\
\hline Netherlands & 9 & 1.98 & 2013 & 4.54 & 6 \\
\hline Italy & 8 & 1.26 & 2013 & 6.34 & 4 \\
\hline Sweden & 8 & 3.30 & 2013 & 2.42 & 10 \\
\hline Finland & 7 & 3.31 & 2013 & 2.11 & 13 \\
\hline Belgium & 6 & 2.28 & 2013 & 2.63 & 8 \\
\hline Australia & 5 & 2.25 & 2011 & 2.22 & 12 \\
\hline Switzerland & 5 & 2.96 & 2012 & 1.68 & 15 \\
\hline Germany & 4 & 2.85 & 2013 & 1.43 & 16 \\
\hline Spain & 4 & 1.24 & 2013 & 3.22 & 7 \\
\hline Brazil & 3 & 1.15 & 2012 & 2.60 & 9 \\
\hline Israel & 3 & 4.21 & 2013 & 0.71 & 18 \\
\hline Hungary & 2 & 1.41 & 2013 & 1.41 & 17 \\
\hline Poland & 2 & 0.87 & 2013 & 2.29 & 11 \\
\hline Russia & 2 & 1.13 & 2013 & 1.76 & 14 \\
\hline
\end{tabular}

Table 4. The top 15 most prominent universities or centers within the T100

\begin{tabular}{|c|c|c|c|c|}
\hline \multirow[t]{2}{*}{ Organization } & \multirow{2}{*}{$\begin{array}{l}\text { Citations within } \\
\text { the T100 }\end{array}$} & \multicolumn{3}{|c|}{ International University Ranking as per } \\
\hline & & ARWU - Shanghai Ranking (2015) [5] & Leiden Ranking (2015) [6] & QS rating (2015) [7] \\
\hline Harvard Univ & 20 & 1 & 2 & 2 \\
\hline Univ Michigan & 12 & 22 & 48 & 30 \\
\hline NCI & 11 & - & - & - \\
\hline Univ California San Francisco & 11 & 18 & 8 & - \\
\hline Washington Univ & 11 & 32 & 29 & 110 \\
\hline Univ Washington & 9 & 15 & 27 & 65 \\
\hline UCLA & 8 & 12 & 20 & 27 \\
\hline Univ Texas & 8 & 37 & 14 & 77 \\
\hline Baylor Coll Med & 6 & $101-150$ & 81 & - \\
\hline Brigham and Women's Hospital & 6 & - & - & - \\
\hline Duke Univ & 6 & 31 & 31 & 29 \\
\hline Columbia Univ & 5 & 8 & 19 & 22 \\
\hline
\end{tabular}

Univ = university; $\mathrm{NCI}=$ National Cancer Institute; $\mathrm{MSKCC}=$ Memorial Sloan Kettering Cancer Center; UCLA=University of California, Los Angeles.

\section{Authorship (Total, First, Co-Author)}

Authors with at least 4 publications within the T100 were tabulated (table 5). The author Catalona W. J., is responsible for the most $(n=4)$ T100 articles as a first author in the observed history of PCa research. The authors Crawford E. D. and Walsh P. C., have both contributed to the most $(\mathrm{n}=7)$ T100 articles as author and co-author combined. The list of the top ranked author list within T100 (number of publications listed as first and co-author) is tabulated (table 6). The top ranked combined first and co-author was Crawford E. D. and Walsh P. C. with 7 cumulative publications within the T100. 


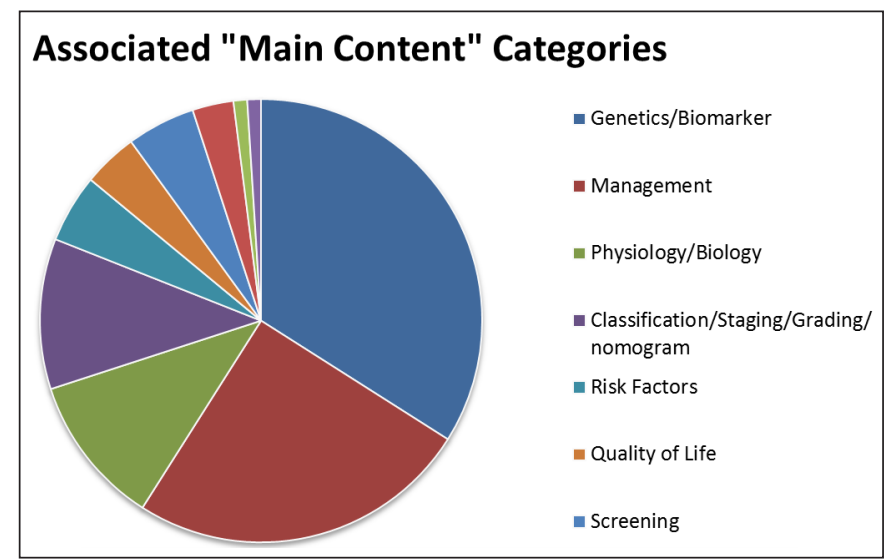

Fig. 2. Actual "content-related" categories associated with PCa.

Table 5. The top ranked first authors within the T100

\begin{tabular}{rll}
\hline Rank of citations & Author & $\begin{array}{l}\text { Number of T100 articles } \\
\text { as first author }\end{array}$ \\
\hline 1 & Catalona W. J. & 4 \\
2 & De Bono J. S. & 3 \\
3 & Gleason D. F. & 3 \\
4 & Partin A. W. & 3 \\
5 & Bolla M. & 2 \\
6 & Epstein J. I. & 2 \\
7 & Giovannucci E. & 2 \\
8 & Heidenreich A. & 2 \\
9 & Kantoff P. W. & 2 \\
10 & Saad F. & 2 \\
\hline
\end{tabular}

\section{Languages of Publication}

All papers included within the T100, were published in the English language.

\section{Discussion}

PCa represents a rapidly evolving field and accounts for a considerable proportion of urological publications within the contemporary medical literature. To better understand this dynamic research focus area, we performed a comparative bibliometric analysis in $\mathrm{PCa}$ research. The findings of the current study demonstrate that North American and European institutions dominate the T100 PCa publications. Further, our findings demonstrate that articles pertaining to PCa genetics and biomarkers represent the highest citation potential.

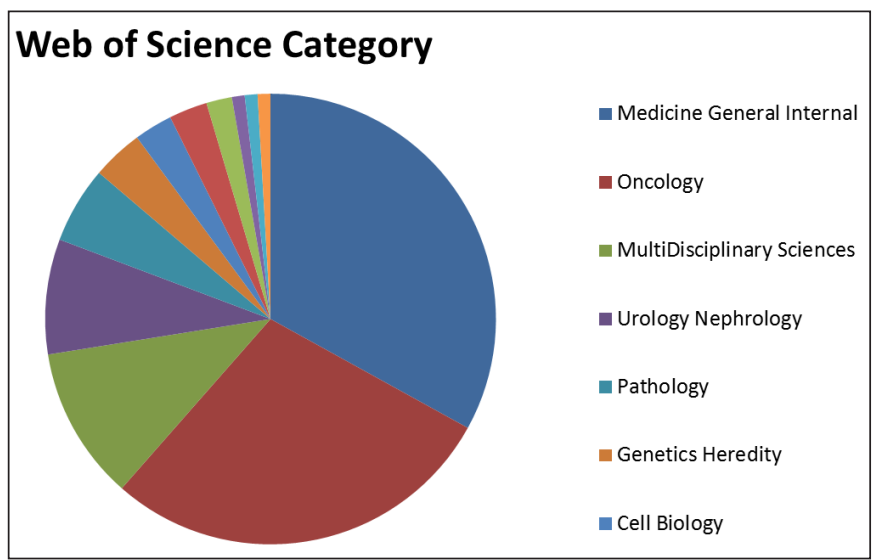

Fig. 3. Web of Science associated categories associated with PCa.

Table 6. Top ranked author list within T100 (number of publications listed as first/co-author)

\begin{tabular}{lllll}
\hline \multirow{2}{*}{$\begin{array}{l}\text { Rank of } \\
\text { citations }\end{array}$} & Author & \multicolumn{3}{c}{ Number of T100 articles } \\
\cline { 3 - 5 } & & Author & First author & Co-author \\
\hline 1 & Crawford E. D. & 7 & 1 & 6 \\
2 & Walsh P. C. & 7 & - & 7 \\
3 & Partin A. W. & 6 & 3 & 3 \\
4 & Scher H. I. & 6 & 2 & 4 \\
5 & Catalona W. J. & 5 & 4 & 1 \\
6 & Giovannucci E. & 5 & 2 & 3 \\
7 & Pienta K. J. & 5 & - & 5 \\
8 & Scardino P. T. & 5 & - & 5 \\
9 & Small E. J. & 5 & 1 & 4 \\
10 & Varambally S. & 4 & 1 & 3 \\
\hline
\end{tabular}

Within medical literature, there is an absence of a universally-accepted absolute bibliometric comparator [13]. As such, CI may represent a useful objective measure of intellectual influence to a particular field. Previous citation bibliometric analyses have been reported in the fields of psoriasis [14], pediatric neuro-surgery [8], spine-related research [15], cardiovascular research [16], dentistry [17], and within adult and pediatric urology [18-21]. These bibliometric evaluations provided a clearer "snapshot" of articles and associated research focus areas which have generated the most "intellectual influence" within the particular research focus area analysed. Despite this, there are inherent limitations in using citation data as a marker of intellectual influence that should be noted. A recent review observed that the CI alone was also not a good marker when reviewing the prescribed or suggested reading or study material when 


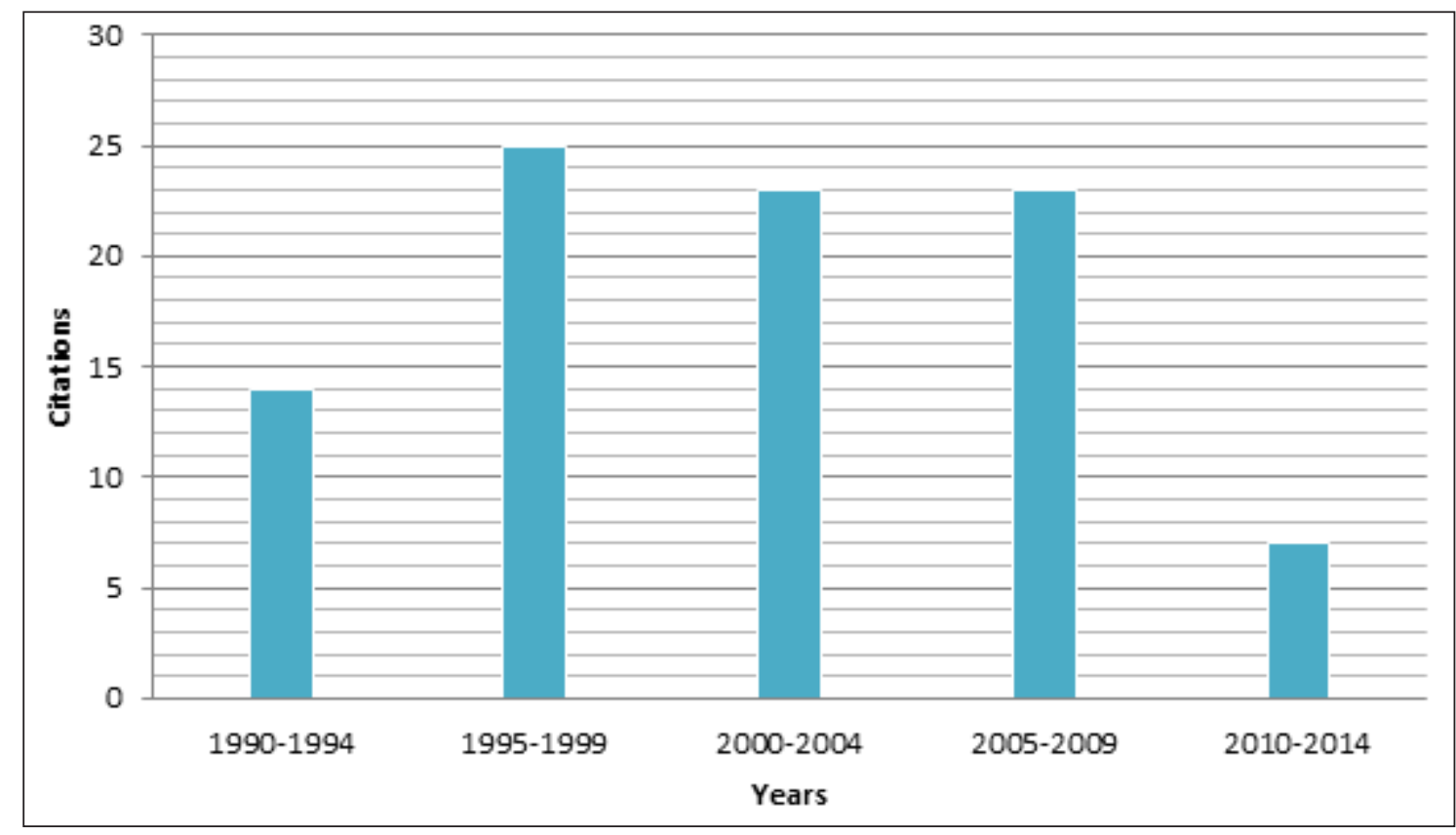

Fig. 4. A 5-year interval bar graph depicting the timeline distribution of the T100 (covering the last 25 years).

preparing for the Fellow of the Royal College of Surgeons Urology Examination [22]. Furthermore, certain strategies are well known to increase the CI. These include using consistent name and affiliations, publishing in high IF journals, using an international collaborative authorship approach or publishing across fields [23].

Our study highlights the predominance of publications originating from institutions located in USA or Europe. Specifically, of the affiliated countries, USA accounted for the largest total (86/203). Further, we identified that medical and oncological journals represented a significant proportion of publications within in the T100, while The Journal of Urology was the highest ranked journal in the "urology and nephrology" category. Our results have corroborated with a previous bibliometric review of the T100 cited articles in "general" urology [19]. Nason et al. [19] observed a majority of the articles originated from USA (77/100), most in the field of oncology (54/100). Further, this group identified that The Journal of Urology published these articles most frequently (16/100) within the journals within the "urology and nephrology" category. These sentiments were further echoed by an earlier review of 1,239 "citation classics" [20], in urology, where a "citation classic" was defined as a paper with a CI of more than 100. In their review, the articles originated from USA accounted for the majority
$(774 / 1,239)$ of papers assessed. Similar to Nason et al. [19] the category of "prostate cancer and PSA" was the most prevalent $(33.5 \%)$ category. Furthermore, amongst the journals assessed, The Journal of Urology had listed the most cites within the "urology and nephrology" category. Controversy exists in the geographical region of distribution of the T100 and the fact that the preferential citation biases from the USA, by other American authors and may lead to an over-estimated CI [10].

An attempt at adjusting for PCa research per country by factoring the percentage of GDP given for research was also explored in this study, and this change is reflected in table 3. Despite adjusting for this variable within our study, the USA is still top ranked. This finding had been previously observed in a review of the "geographical origin" of publications within the urological literature, where adjusting the ranking using the percentage spent on research per GDP, did have an impact on the overall rank [10]. This may be explained by the previously noted "preferential citation biases" from the USA, by other American authors, which in turn may lead to an over-estimated CI [10].

Certain content relevant to $\mathrm{PCa}$ research may be highly citable and may not be contained in the "urology and nephrology" journal category, so we opted not to include a limitation to the journal category searched. This 
allowance proved to be significant, since the top ranked article in the T100 [24], was published in a category outside the "urology and nephrology" journal category.

There are several limitations to the current study. Firstly, as previously discussed, there are inherent limitations in using citation data in bibliometric analyses. Secondly, our study utilized only the Web of Science Database. A number of alternate databases that calculate citation metrics are available including Google Scholar, Science Direct and EMBASE. The Web of Science was selected as it includes "older" publications, although the Scopus database is more extensive in more recent literature records. Nevertheless, Web of Science database was utilized as the duration of publication has a greater impact on citation [25]. Thirdly, this study did not review actual book chapters or book content, and unpublished $\mathrm{Ph} . \mathrm{D}$. and masters dissertations were also not assessed. These were excluded in the search term as the book databases are less encompassing and thus citation records would prove challenging to review.

Furthermore, there may well be research content that may have had an influence but has not been cited or not cited correctly. Also, publication bias or un-blinded peer-review, may also play a role in the publication process, where more prominent authors or institutions have preference over others. Further, the citation score may not always reflect the inherent quality of a particular finding, research paper. The topic of "prostate cancer" is indeed a multifaceted, so isolating a certain subset within this field may have been more accurate in the assessment process. Self or over citation of author's publications may also weigh heavily on the CI, sometimes without appropriate merit. Finally, a hallmark paper by Huggins and Hodges (1941) [26], was excluded due to our study search date limitation (1945-2016). Their article was the first translational research study in hormonal therapy and $\mathrm{PCa}$ and earned the first author Charles Brenton Huggins, a Nobel prize in the category of physiology or medicine in the year 1966 [27]. A citation search on the Web of Science performed for their article returned 2,578 citations, which would have placed this third on the overall CI ranking in the T100.

In conclusion, despite the controversies involved in the CI of published research, it has remained a recording measure of academic, peer-reviewed research. We present the first comparative, bibliometric study to review the CI and citation metrics in the field of PCa research. Geographic regions that pre-dominate the literature amongst the T100 include North America and Europe. Publications originating from higher IF journals, English language medium of publication, original article format and multi-center collaborative research was observed to be more prominent amongst the T100. Areas within PCa research that are related to the content category of genetics and biomarkers have the highest citation potential. Amongst the journal category "urology and nephrology", most T100 were published in The Journal of Urology. When assessing within all journal categories, The New England Journal of Medicine leads the list. All these above mentioned factors may have an implication on future citation potential in $\mathrm{PCa}$ research, the funding and choice of associated research focus that academic urologists take in the future.

\section{Acknowledgments}

We wish to sincerely thank Professor Yvonne Reed, Ph.D. (School of Education, University of the Witwatersrand, Johannesburg) and Mr. Devind Peter and Ms. Cecilia Ford (Faculty of the Health Sciences Library at the University of the Witwatersrand, Johannesburg) for their research support. We are also indebted to Mrs. Anna Welman (Department of Surgery, Helen Joseph Hospital, University of the Witwatersrand, Johannesburg) for her secretarial aid. 


\section{References}

1 Siegel RL, Miller KD, Jemal A: Cancer statistics, 2016. CA Cancer J Clin 2016;66:7-30.

2 Ferlay J, Soerjomataram I, Dikshit R, Eser S, Mathers C, Rebelo M, Parkin DM, Forman D, Bray F: Cancer incidence and mortality worldwide: sources, methods and major patterns in GLOBOCAN 2012. Int J Cancer 2015;136:E359-E386.

3 Kulkarni AV, Busse JW, Shams I: Characteristics associated with citation rate of the medical literature. PLoS One 2007;2:e403.

4 Journal Citation Reports: http://ipscience. thomsonreuters.com/product/journal-citation-reports/?utm_source=false\&utm_medium=false\&utm_campaign=false, last accessed on 20 February 2016.

5 Shanghai Ranking: http://www.shanghairanking.com, last accessed on 25 July 2016.

6 Leiden Ranking: http://www.leidenranking. com, last accessed on 25 July 2016.

7 QS World Ranking: http://www.topuniversities.com/qs-world-university-rankings, last accessed on 25 July 2016.

8 Wilcox MA, Khan NR, McAbee JH, Boop FA, Klimo P Jr: Highly cited publications in pediatric neurosurgery. Childs Nerv Syst 2013;29:2201-2213.

9 World Bank DATA: http://data.worldbank. org/indicator/GB.XPD.RSDV.GD.ZS, accessed on 2 Feb 2016.

10 McGuire BB, Burke JP: Geographic origin of publications in urological journals. Curr Urol 2008;2:20-23.
11 Kantoff PW, Higano CS, Shore ND, Berger ER, Small EJ, Penson DF, Redfern CH, Ferrari AC, Dreicer R, Sims RB, Xu Y, Frohlich MW, Schellhammer PF: Sipuleucel-T immunotherapy for castration-resistant prostate cancer. N Engl J Med 2010;363:411-422.

12 Gleason DF: Classification of prostatic carcinomas. Cancer Chemother Rep 1966;50:125128.

13 Cleaton-Jones P, Myers G: A method for comparison of biomedical publication quality across ISI discipline categories. J Dent Educ 2002;66:690-696.

14 Wu JJ, Choi YM, Marczynski W: The 100 most cited psoriasis articles in clinical dermatologic journals, 1970 to 2012. J Clin Aesthet Dermatol 2014;7:10-19.

15 Murray MR, Wang T, Schroeder GD, Hsu WK: The 100 most cited spine articles. Eur Spine J 2012;21:2059-2069.

16 Shuaib W, Khan MS, Shahid H, Valdes EA, Alweis R: Bibliometric analysis of the top 100 cited cardiovascular articles. Am J Cardiol 2015;115:972-981.

17 Feijoo JF, Limeres J, Fernández-Varela M, Ramos I, Diz P: The 100 most cited articles in dentistry. Clin Oral Investig 2014;18:699_ 706.

18 Hennessey K, Afshar K, MacNeily AE: The top 100 cited articles in urology. Can Urol Assoc J 2009;3:293-302.

19 Nason GJ, Tareen F, Mortell A: The top 100 cited articles in urology: an update. Can Urol Assoc J 2013;7:e16-24.
20 Heldwein FL, Rhoden EL, Morgentaler A: Classics of urology: a half century history of the most frequently cited articles (19552009). Urology 2010;75:1261-1268.

21 O'Kelly F, Nason GJ, McLoughlin LC, Flood HD, Thornhill JA: A comparative bibliometric analysis of the top 150 cited papers in hypospadiology (1945-2013). J Pediatr Urol 2015;11:85.e1-11.

22 McLoughlin LC, O'Kelly F, Thornhill JA: Is citation index a good indicator of landmark papers in urology? J Clin Urol 2015;8:110 126.

23 Ale Ebrahim N, Salehi H, Embi MA, Tanha FH, Gholizadeh H, Motahar SM, Ordi A: Effective strategies for increasing citation frequency. Int Educ Studies 2013;6:93.

24 Li J, Yen C, Liaw D, Podsypanina K, Bose S, Wang SI, Puc J, Miliaresis C, Rodgers L, McCombie R, Bigner SH, Giovanella BC, Ittmann M, Tycko B, Hibshoosh H, Wigler MH, Parsons R: PTEN, a putative protein tyrosine phosphatase gene mutated in human brain, breast, and prostate cancer. Science 1997; 275:1943-1947.

25 Falagas ME, Pitsouni EI, Malietzis GA, Pappas G: Comparison of PubMed, Scopus, Web of Science, and Google Scholar: strengths and weaknesses. FASEB J 2008;22:338-342.

26 Huggins C, Hodges CV: Studies on prostatic cancer 1. Cancer Res 1941;1:293-297.

27 Nobel Laureate: https://www.nobelprize.org/ nobel_prizes/medicine/laureates/, last accessed 20 August 2016. 